\title{
Tafsir Kontemporer: Metodologi, Paradigma dan Standar Validitasnya
}

\author{
Eni Zulaiha \\ Fakultas Ushuludin UIN Sunan Gunung Djati Bandung \\ Jl A.H Nasution No 105 Bandung, Jawa Barat, Indonesia \\ E-mail: enzul72@gmail.com
}

\begin{abstract}
Feminist exegesis (tafsir) is a unique genre emerges in contemporary era when gender issue become a global concern. The paradigm of this tafsir started from the asumpsion that the Qur'anic principle of male-female relationship should be based on justice (al-'adalah), equality (al-musawah), appropriateness (al-ma'ruf), and conssensus (syura). Thus, any exegesis produced in classical period which violate all those principles are considered unacceptable, especially in relation to the current situation which differ from that of previous time. Feminist tafsir employs gender analisys as a tool to differentiate between God given condition that is unchangeable to gender as social construction that is changeable. In addition, hermeneutics is considered an appropriate approach chosen in feminist tafsir along with thematic method to interprete verses about gender relation in the Qur'an. With this methodology, its aim is to produce tafsir with more intersubjective and critical insight related to gender relation.
\end{abstract}

Keywords:

Feminist interpretation; history; validity feminist interpretation.

\begin{abstract}
Abstrak
Tafsir feminis adalah sebuah genre tersendiri yang muncul di era kontemporer ketika isu gender menjadi isu global. Paradigma tafsir ini berangkat dari asumsi, bahwa prinsip dasar al-Qur'an dalam relasi laki-laki dan perempuan adalah keadilan (al-'adalah), kesetaraan (al-musawah), al-ma'ruf (kepantasan), syura (musyawarah). Sehingga produk-produk penafsiran klasik yang bertentangan dengan prinsip-prinsip tersebut akan dinilai tidak tepat, terutama ketika diterapkan untuk konteks kekininian, sebab situasi dan kondisinya jelas berbeda sama sekali dengan zaman dulu. Model analisis yang dipakai dalam paradigma tafsir feminis adalah analisis gender,yang secara tegas membedakan antara kodrat sebagai sesuatu yang tidak bisa berubah, dengan gender sebagai konstruksi sosial yang bisa berubah. Wajar jika kemudian pendekatan hermeneutik dengan metode tafsir tematik akhirya menjadi pilihan dalam mengkaji ayat-ayat tentang relasi gender. Sebab dengan metodologi seperti itu, diharapkan produk tafsir akan lebih intersubyektif dan kritis melihat problem relasi gender.
\end{abstract}

Kata Kunci:

Sejarah; tafsir feminis; validitas tafsir feminis.

DOI: $10.15575 / \mathrm{jw} . \mathrm{v} 2 \mathrm{i} 1.780$

Received: June 2016; Accepted: June 2017; Published: June 2017 


\section{A. PENDAHULUAN}

Tafsir awalnya lebih merupakan ilmu yang sangat teknis, mulai dari bagaimana cara membaca Alquran, i'rabnya, sampai pada bagaimana memahami kandungan Alquran. Maka objek kajian tafsir pada saat itu masih sangat luas. Muhammad Ali Salamah, Husein Al-Dzahabi yang dan Khalid ibn Usman yang mempersempit definisi tafsir menjadi ilmu yang yang mengkaji kompleksitas Alquran dalam rangka memahami firman Allah SWT sesuai kadar kemampuan manusia. Maka bisa disimpulkan bahwa objek material tafsir adalah Alquran, sedang objek formal tafsir itu adalah problem pemberian makna dan memproduksi makna untuk mengungkap maksud firman Allah. Jika demikian, maka seorang penafsir hanya berkewajiban memahami maksud Allah dalam Alquran sesuai kemampuan keilmuan dan latar belakang yang melingkupinya. Seorang penafsir hanya seorang yang mencoba mencari kebenaran dan bukan penentu kebenaran. Oleh karenanya, tafsir pada posisi seperti ini bukan suatu produk yang final, dan tafsir harus selalu dipahami dengan cara mengingat latar ilmu dan latar kehidupan saat mufasir itu menuliskannya. Berkenaan dengan ini Syahrur pernah mengkritik bahwa idealnya tafsir harus merupakan kajian ilmiah yang objektif atas teks suci keagamaan. Makanya ia tidak boleh dilandasi oleh kepentingan-kepentingan tendensius, sebab hal itu akan menjerumuskan seseorang pada kearagu-raguan dan menyebabkan hilangnya nilai objektifitas penafsiran ${ }^{1}$

Sekilas memang tidak ada bedanya antara tafsir kontemporer dengan tafsir klasik, keduanya memang difokuskan untuk menyelaraskan pesan Alquran dengan kondisi zamannya. Namun di masa kontemporer dampak kemajuan ilmu pengetahuan dan tehnologi menjadi faktor utama yang mengarah pada tuntutan baru. Hal lain yang turut mempengaruhi tafsir kontemporer adanya beberapa dasar pemikiran moderen yang telah terlebih dahulu ada dalam

${ }^{1}$ Syahrur, al-Kitab wa al-Qur,an; Qiraah Mu'ashiroh (Damaskus: Ahali li al-Nasyr wa al-awzi 1992 hal 30 merespon Alquran sehingga tafsir di abad kontemporer memiliki asumsi dan paradigma yang berbeda dengan tafsir di masa awal.

Jika pada tradisi penafsiran klasik prinsip bahwa Alquran shalih likulli zaman wa makan dipahami secara paksa pada konteks apa pun ke dalam teks Alquran. Akibatnya, pemahaman yang muncul cenderung tekstualis dan literalis. Maka pada tafsir kontemporer, prinsip tersebut dipahami lebih kontekstual. Sehingga hasil penafsirannya bukan hanya pada persoalan makna kata, namun lebih pada penemuan ideal moral dari tiap ayat Alquran yang merupakan hasil kolabarosi penggunaan analisa makna kata, analisa sosial dan analisa historis.

Menurut hemat penulis ada dua hal yang menjadi dasar pentingnya pembahasan tentang paradigma, metodologi dan validitas tafsir kontemporer menjadi penting. Pertama sering terjadinya kesalahpahaman dalam menilai sebuah tafsir sehingga dengan mudah menilai bahwa sebuah tafsir itu sesat hanya karena berbeda metodologi. Kedua membahas paradigma, metodologi dan validitas tafsir kontemporer adalah mengenalkan dengan rinci tentang akar akar yang membuat tafsir ini berbeda dengan tafsir yang selama ini ada, sehingga penjabaran tentang tafsir kontemporer secara metodologis dapat menjadi filtrasi terhadap tuduhan miring pada tafsir ini. Tulisan ini bermaksud membahas paradigma, standar validitas dan berbagai pendekatan yang digunakan tafsir Alquran di zaman kontemporer. Dalam tulisan ini akan digunakan metode deskriptif analitis dalam pembahasannya, yakni sebuah metode yang bermaksud memaparkan secara rinci tentang tafsir kontemporer, lalu menganalisa bagian mana yang termasuk pada paradigmanya dan bagaimana standar validitasnya.

\section{B. HASIL DAN PEMBAHASAN \\ 1. Tafsir Alquran di zaman kontemporer}

Kata tafsir secara etimologi berasal dari bahasa Arab dari kata fassara yufassiru tafsìran, yang artinya memeriksa-memperlihatkan, atau 
bermakna kata الايضـاح والشرح penjelasan atau komentar. $^{2}$

Secara terminologi tafsir adalah penjelasan terhadap kalamullah atau menjelaskan lafal Alquran dan pemahamannya. ${ }^{3}$ Pandangan senada diungkapkan oleh Al-Qaththan, bahwa tafsira dalah ilmu untuk memahami kitābullāh yang diturunkan kepada Nabi Muhammad, menjelaskan makna-maknanya, serta mengeluarkan hukum dan hikmahnya. ${ }^{4}$

Abu Hayyan dalam al-Bahrul Muhit, sebagaimana dikutip oleh as-Suyuthi, menjelaskan bahwa tafsir adalah ilmu yang membahas tentang cara menjelaskan lafal-lafal Alquran, maksud-maksudnya, berbagai hukumnya dan makna yang terkandung di dalamnya. ${ }^{5}$

Sementara kata kontemporer berarti sezaman atau sewaktu. ${ }^{6}$ Di dalam kamus Oxford Learner's Pocket Dictionary dijelaskan, ada dua pengertian dari contemporary. Pertama belonging to the same time (termasuk waktu yang sama), dan yang kedua, of the present time; modern (waktu sekarang atau modern). ${ }^{7}$ Sedangkan dalam bahasa Indonesia, kontemporer adalah pada masa kini atau dewasa ini. ${ }^{8}$

Pada dasarnya tidak ada kesepakatan yang jelas tentang arti istilah kontemporer. Misalnya apakah istilah kontemporer meliputi abad ke-19 atau hanya merujuk pada abad ke-20 s.d 21. Menurut Ahmad Syirbasyi yang dimaksud dengan periode kontemporer adalah yaitu sejak abad ke 13 hijriah atau akhir abad ke-19

\footnotetext{
${ }^{2}$ A.W. Munawir, Kamus Al-Munawir ArabIndonesia Lengkap (Surabaya: Pustaka Progresip, 1997).

${ }^{3}$ Abdul Hamid Al-Bilali, Al-Mukhtashar Al-Mashun Min Kitab Al-Tafsir Wa Al-Mufashirun (Kuwait: Dar alDakwah, 1405).

${ }^{4}$ Manna' Khalil Qaththan, Studi Ilmu-Ilmu AlQur'an (Jakarta Timur: Pustaka al-Kautsar, 2008).

${ }^{5}$ Al-Hafizh al-Imam Jalaluddin Suyuthi, Al-Itqan (Kairo: Dar At-Turath, n.d.)., 925.

${ }^{6}$ John M. Echols dan Hasan Sadily, Kamus InggrisIndonesia (Jakarta: Gramedia, 2003)., 143.

${ }^{7}$ Anonim, Oxford Learner's Pocket Dictionary, New Edition (Oxford: Oxford University Press, 2006)., 90.

${ }^{8}$ Pusat Bahasa Departemen Pendidikan Nasional, Kamus Besar Bahasa Indonesia (Jakarta: Gramedia, 2003).
}

Masehi sampai sekarang ini. ${ }^{9}$ Sebagian pakar berpandangan bahwa kontemporer identik dengan modern, keduanya saling saling digunakan secara bergantian. Dalam konteks peradaban Islam keduanya dipakai saat terjadi kontak intelektual pertama dunia Islam dengan Barat. Kiranya tak berlebihan bila istilah kontemporer disini mengacu pada pengertian era yang relevan dengan tuntutan kehidupan modern. ${ }^{10}$

Dengan demikian, dapat disimpulkan bahwa Tafsir Kontemporer ialah Tafsir atau penjelasan ayat Alquran yang disesuaikan dengan kondisi kekinian atau saat ini. Pengertian seperti ini sejalan dengan pengertian tajdid yakni usaha untuk menyesuaikan ajaran agama dengan kehidupan kontemporer dengan jalan mentakwilkan atau menafsirkan sesuai dengan perkembangan ilmu pengetahuan serta kondisi sosial masyarakat. ${ }^{11}$

Adapun problem kemanusiaan yang muncul dihadapan adalah seperti; masalah Kemiskinan, Pengangguran, Kesehatan, Ketidakadilan, Hukum, Ekonomi, Politik, Budaya, Diskriminasi, Sensitifitas Gender, HAM dan masalah ketimpangan yang lain. Sehingga dengan demikian metodologi tafsir kontemporer adalah kajian di sekitar metode-metode tafsir yang berkembang pada era kontemporer.

Namun demikian, apabila definisi di atas tidak dipahami dengan cermat, maka akan menyesatkan banyak orang, sebab akan terkesan bahwa Alquran harus mengikuti perkembangan zaman. Sebuah statemen yang tidak boleh diucapkan oleh siapapun. Secara terperinci maksud dari tafsir modern kontemporer adalah; merekonstruksi kembali produkproduk tafsir klasik yang sudah tidak memiliki relevansi dengan situasi modern. ${ }^{12}$ Seperti

\footnotetext{
${ }^{9}$ Ahmad Syirbasi, Studi Tentang Sejarah Perkembangan Tafsir Al-Qur'anul Karim (Jakarta: Kalam Mulia, 1999).

${ }^{10}$ Ahmad Syukri, Metodologi Tafsir Al-Qur'an Kontemporer Dalam Pandangan Fazlur Rahman (Jambi: Sulton Thaha Press, 2007).

${ }^{11}$ M. Quraisy Shihab, Membumikan Al-Qur'an (Bandung: Mizan, 1998).

${ }^{12}$ Rosihon Anwar, Samudra Al-Qur'an (Bandung: Pustaka Setia, 2001).
} 
yang sudah disinggung di atas, bahwa tafsir kontemporer ialah 'Tafsir atau penjelasan ayat Alquran yang disesuaikan dengan kondisi kekinian atau saat ini'yang tentunya berbeda dengan tafsir klasik.

Kemunculan Tafsir kontemporer erat kaitannya dengan mulai muncul istilah pembaharuan yang dipopulerkan oleh beberapa ulama moderen kontemporer yang menginginkan pendekatan dan metodologi baru dalam memahami Islam. Persepsi para pembaharu memandang bahwa Pemahaman Alquran yang terkesan jalan di tempat ${ }^{13}$. Alih alih mereka memandang bahwa metodologi klasik telah menghilangkan ciri khas Alquran sebagai kitab yang sangat sempurna dan komplit sekaligus dapat menjawab segala permasalahan klasik maupun modern. ${ }^{14}$

Sebut saja Ali Harb misalnya (untuk tidak menyebut semuanya). Ia menyarankan pembacaan kritis pada tafsir Alquran. Menurutnya, pembacaan kritis itu adalah pembacaan atas teks Alquran yang selama ini tak terbaca dan ingin menyingkapkan kembali apa yang tak terbaca itu. ${ }^{15}$ Lalu Nashr Hamid Abu Zayd menyebut Alquran sebagai produk budaya, yakni teks yang muncul dalam sebuah struktur budaya Arab abad ketujuh, selama lebih dari dua puluh tahun dan ditulis dengan berpijak pada aturan-aturan budaya tersebut. ${ }^{16}$ Keuniversalan petunjuk-petunjuk dalam Alquran itu dapat dirumuskan dengan selalu mengasumsikan dan mempertimbangkan kondisi sosiohistoris yang muncul ketika itu, lalu diusahan dikontekstualkan dengan kondisi kekinian. Syahrur pernah mengkritik bahwa idealnya tafsir harus merupakan kajian ilmiah yang objektif atas teks suci keagamaan (al-Nash alQudsy). Makanya ia tidak boleh dilandasi oleh kepentingan-kepentingan tendensius, sebab hal

\footnotetext{
${ }^{13}$ Kuntowijoyo, Islam Sebagai Ilmu (Yogyakarta: Tiara Wacana, 2006).

${ }^{14}$ Muhammad Sayyid Thanthawi, Mabahits Fi "Ulum Al-Qur"an (Kairo: Azhar Press, 2003).

${ }^{15}$ Ali Harb, Naqd an-Nashsh, (Beirut: al-Markaz atsTsaqafi, 1995), hlm. 204-205.

${ }^{16}$ Nashr Hamid Abu Zaid, Mafhum an-Nash: Dirasat fi 'Ulum Al-Qur'an, (Kairo: al-Hay'ah al-Mishriyyah al'Ammah li al-Kitab, 1993), hlm. 27-28.
}

itu akan menjerumuskan seseorang pada kearagu-raguan dan menyebabkan hilangnya nilai objektifitas penafsiran ${ }^{17}$

Fazlur Rahman misalnya menggagas metode tematik-kontekstual. Menurut Rahman, ayat-ayat Alquran tidak bisa dipahami hanya secara literal saja, sebagaimana yang dipahami oleh para penafsir klasik. Menurutnya, memahami Alquran dengan cara mengambil makna harfiahnya saja bukan hanya akan menjauhkan seseorang dari petunjuk yang diberikan Alquran, melainkan hal itu juga merupakan upaya pemaksaan terhadap ayat-ayat Alquran itu sedangkan sendiri.

Menurut Fazlur Rahman, pesan yang sesungguhnya ingin disampaikan Alquran kepada umat manusia bukanlah makna yang ditunjukkan oleh ungkapan harfiah itu sendiri, melainkan ideal moral yang ada di balik ungkapan literal tersebut. Oleh karena itu, ayat-ayat Alquran harus dipahami dari sisi pesan moral dan maqashid asy-syari'ah-nya.

Guna menemukan pesan moral yang terkandung dalam ayat-ayat Alquran, Fazlur Rahman kemudian mengusulkan tentang urgensi pada pengkajian situasi dan kondisi historis yang melatarbelakangi turunnya ayatayat Alquran, baik berupa asbāb an-nuzūl maupun situasi sosial, politik, ekenomi, budaya, dan juga peradaban masyarakat saat Alquran diturunkan. Bagi Fazlur Rahman, ayat-ayat Alquran adalah pernyataan moral, religius, dan sosial Tuhan untuk merespons apa yang terjadi dalam masyarakat. Di dalam ayat-ayat itulah terdapat apa yang oleh Rahman disebut ideal moral, yang pada giliran selanjutnya ideal moral inilah yang harus dijadikan acuan dalam memahami ayat-ayat Alquran. Menurut Mustaqim, dengan memakai pendekatan hermeneutika model Emilio Betti, Rahman menawarkan hermeneutika double movement, yakni model penafsiran Alquran yang ditempuh melalui gerak ganda: bergerak dari situasi sekarang menuju ke masa

17 Syahrur, al-Kitab wa al-Qur,an; Qiraah Mu'ashiroh (Damaskus: Ahali li al-Nasyr wa al-awzi 1992 hal 30 
di mana Alquran diturunkan untuk kemudian ditarik kembali ke masa kini.

Selaras dengan itu, kajian tentang Alquran dalam khazanah intelektual Islam memang tidak pernah mandeg. Setiap generasi memiliki tangung jawab masing-masing untuk menyegarkan kembali kajian sebelumnya, yang di anggap sudah out of date. ${ }^{18}$ Kemunculan metode tafsir kontemporer diantaranya dipicu oleh kekhawatiaran yang akan ditimbulkan ketika penafsiran Alquran dilakukan secara tekstual, dengan mengabaikan situasi dan latar belakang turunnya suatu ayat sebagai data sejarah yang penting. ${ }^{19}$

\section{Tantangan Tafsir Alquran di Zaman Kontemporer}

Disadari atau tidak, Globalisasi yang melanda dunia memaksa umat Islam untuk merumuskan kembali berbagai pemikiran keislaman. Pesatnya Teknologi informasi yang berkembang akhir-akhir ini telah menyebabkan terjadinya perubahan yang demikian kompleks dalam kelihidupan umat Islam. Pergolakan "emansipasi", "demokrasi" dan "reformasi" di bagian wilayah lain dunia ini dengan begitu mudah diakses umat Islam, dan ini sangat mempengaruhi kehidupan umat Islam.

Perubahan sosial yang diakibatkan oleh globalisasi menyebabkan pemikiran-pemikiran keislaman lama mengalami "keterasingan" karena tidak mampu memberikan jawaban atas berbagai tantangan baru yang muncul akibat perubahan tersebut. Munculnya tantangantantangan baru ini mengharuskan dirumuskannya kembali pemikiran-pemikiran Islam agar bisa menjawab tantangan-tantangan tersebut. Masuknya gagasan feminisme dan pluralisme di kalangan umat Islam juga jelas tidak bisa dilepaskan dari perkembangan global yang melanda umat Islam.

Gagasan tentang HAM merupakan tantangan berikutnya bagi Tafsir Alquran di zaman

\footnotetext{
${ }^{18}$ Nurcholish Setiawan, “Al-Qur`an Dalam Kesejarahan Klasik \& Kontemporer,” Jurnal Study AlQur'an, (2006), 93.

${ }^{19}$ Ahmad Syukri, Metodologi Tafsir Al-Qur'an Kontemporer, 58.
}

kontemporer. Berbagai persoalan sosial dan kemanusiaan berjalin kelindan dengan pencarian jawaban dari Alquran tentang isu global ini. Serangan Barat yang demikian ini kepada Islam yang agaknya menyadarkan pemikirpemikir Islam untuk merumuskan kembali ajaran Islam yang secara moral ternyata sangat membela egalitarianisme dan semangat rahmatan lil 'ālaminn. Namun yang sesungguhnya yang lebih menggerakkan mereka adalah tantangan dunia modern yang menuntun pelaksanaan Hak Asasi Manusia secara menyeluruh.

Hal yang tidak bisa dianggapa sepele, karena banyak memberikan tantangan baru bagi lahirnya berbagai pendekatan ke tafsir Alquran di zaman kontemporer adalah sentuhan dengan (peradaban) Barat. Beberapa ilmuilmu sosial mampu menyedot perhatian para pembaharu Islam untuk mencoba mencari solusi dari persolan yang menghadang masyarakat muslim dunia pada saat ini. Kemampuan mereka memahami ilmu-ilmu sosial, digunakan untuk memahami gejala-gejala keagamaan yang sejauh ini hanya didasarkan pada ilmu-ilmu agama. ilmu sosial yang berasal dari Barat itu sangat penting untuk memahami (mengkritik) gejala (agama) yang ada dalam dunia Islam selama ini.

Tantangan berikutnya bagi tafsir Alquran adalah tantangan Perkembangan Global, Munculnya penafsiran baru atas ayat-ayat Alquran tentang relasi laki-laki-perempuan, tidaklah terlepas dari kesadaran umat manusia dalam masyarakat modern yang dikondisikan oleh konsep Hak Asasi Manusia dan martabat manusia. ${ }^{20}$ Kedua konsep ini, yakni hak asasi dan martabat manusia, memang merupakan wacana ummat Islam kontemporer dalam rangka memenuhi apa yang oleh Bassam Tibi disebut dengan "moralitas internasional", sebuah parameter teoretis yang dikedepankan guna mengatasi konflik antar peradaban Islam dan Barat. $^{21}$ Dalam pandangan Bassam Tibi,

\footnotetext{
${ }^{20}$ Engineer, Hak-Hak Perempuan, 3.

${ }^{21}$ Moralitas internasional merupakan upaya sekularisasi dengan maknanya yang terbatas, yakni pemisahan antara agama sebagai suatu keyakinan etika
} 
hak asasi dan martabat manusia adalah elemen pemersatu (the uniting element) bagi kedua peradaban yang berseteru tersebut untuk mengatasi konflik yang terjadi di antara keduanya. $^{22}$

Dengan pertimbangan seperti ini, maka menurut Engineer, hanya tersedia dua pilihan: apakah kitab suci ini akan diabaikan ataukah harus dibaca ulang dan diinterpretasikan agar tidak bertentangan dengan tuntutan modernitas $?^{23}$ Jika pilihan pertama yang diambil, tentu saja norma-norma lama yang mendukung keberpihakan pada kelompok tertentu dan patriarkat itu akan diabaikan. Namun,jika pandangan inidi tolak, akan mempertajam konflik antara Islam dan Barat. Posisi umat Islam di dunia akan terasing, atau malah selalu dimusuhi Barat. ${ }^{24}$

Dengan mengambil pilihan yang kedua, bukannya persoalan menjadi selesai, kerena jika tidak hati-hati maka yang akan terjadi adalah dominasi Barat terhadap Islam. Namun dominasi ini akan hilang dengan adanya meminjam istilah Bassam Tibi Moralitas Internasional yang disepakati antara Islam dan Barat untuk menggalang dialog. Konsep Hak Asasi Manusia menuntut keadilan bagi umat manusia yang tidak dikaitkan dengan persoalan agama, etnis, jenis kelamin dan lain-lain. Sehingga nilai kesetaraan anatar seluruh anggota bangsa itu harus tetap diperjuangkan. ${ }^{25}$

dengan politik. Ini dilandaskan atas konsensus minimal yang dimiliki peradaban yang berbeda, dalam kaitan ini adalah Islam dan Barat. Tentu saja moralitas internasional bukan didasarkan atas konsep yang sama persis mengenai berbagai hal semisal hak asasi manusia, demokrasi atau yang lain. Masing-masing pihak tetap diberikan untuk bisa berbicara mengenai konsep-konsep internasional tersebut dengan lidah mereka sendiri, yakni dengan mempraktikkan konsep moralitas internasional yang tidak dipaksakan kepada pihak tertentu. Dalam moralitas internasional keragaman tentu tetap ada. Bassam Tibi, "Moralitas Internasional".

${ }^{22}$ Bassam Tibi, "Moralitas Internasional Sebagai Suatu Landasan Lintas Budaya," dalam Agama Dan Dialog Antar Peradaban (Jakarta: Yayasan Wakaf Paramadina, 1996), 143-156.

${ }^{23}$ Enginer, Hak-hak Perempuan, 3.

${ }^{24}$ Enginer, Hak-hak Perempuan, 3.

25 Bandingkan dengan gagasan Mahmoud Muhammad Thaha yang memandang perlunya

\section{Prinsip dan Berbagai Orientasi dan Pendekatan Dalam Tafsir Kontemporer}

Seperti yang telah disinggung di awal, Tafsir kontemporer adalah tafsir atau penjelasan ayat Alquran yang disesuaikan dengan kondisi kekinian atau saat ini. Pengertian seperti ini sejalan dengan pengertian tajdid yakni usaha untuk menyesuaikan ajaran agama dengan kehidupan kontemporer dengan jalan mentakwilkan atau menafsirkan sesuai dengan perkembangan ilmu pengetahuan serta kondisi sosial masyarakat. ${ }^{26}$

Ada perbedaan prinsipal dalam tafsir Alquran di abad kontemporer dengan abad abadsebelumnya. Prinsip prinsip tersebut dibangun pada paradigma yang ada di abad ini. Paradigma itu sendiri lahir atau dirumuskan oleh para ahli karena tafsir menghadapi berbagai tantangan di atas. ${ }^{27}$ Beberapa ulama menyimpulkan bahwa paradigmanya sebagai berikut: pertama, tafsir kontemporer ini bersemangat mengembalikan Alquran sebagai kitab petunjuk. Sebelum itu, Alquran bagi mufasir kontemporer diasumsikan sebagai wahyu yang progresif, maka mereka mengembangkan suatu medel pembacaan yang lebih kritis dan produktif. Ali al-Harbi menjelaskan, bahwa pembacaan kritis pada Alquran adalah pembacaan atas teks Alquran yang tidak terbaca, dan ingin menyingkap kembali apa yang tak terbaca itu. ${ }^{28}$

Selain itu penafsir klasik juga menyakini bahwa Alquran tidaklah turun pada masyarakat hampa budaya, Ia lahir dalam struktur bangsa Arab abad ke tujuh. Ia juga ditulis dengan berpijak pada aturan-aturan budaya bangsa Arab selama dua puluh tahun. Maka petunjuk-petunjuk Alquran yang bersifat uni-

reinterpretasi syariah agar hukum Islam bisa diterima menjadi hukum internasional. Abdullahi Ahmad AnNaim, Dekonstruksi Syari'ah (Yogyakarta: LKiS, 1994).

${ }^{26}$ M. Quraisy Shihab, Membumikan Al-Qur'an, 93.

27 Paradigma adalah seperangkat pra anggapan konseptual, metafisik dan metodologis dalam tradisi kerja ilmiah.

${ }^{28}$ Ali Al-Harb, Naqd Al-Nash (Beirut: al-Markaz alTsaqafi, 1995), 204-205. 
versal juga dapat dirumuskan dengan mepertimbangkan situsi-historis masa itu, untuk kemudian dirumuskan kembali sesuai dengan konteks kekinian.

Kedua, berbeda dengan tafsir klasik yang berkonsentrasi pada kajian makna kata dari segi i'rab dan penjelasan segi teknis kebahasan yang di kandung oleh redaksi ayat, maka paradigma tafsir kontemporer lebih menitik beratkan pada kajian epistemologis-metodologis. Penitik beratan aspek tersebut melahirkan pandangan yang mencoba mencari ada apa di balik teks Alquran, karena yang dinginkan mereka hasil pembacaan yang produktif terhadapAlquran bukan pembacaan yang repetitif. Mereka tidak berhenti pada pemaknaan literal dari ayat-ayat Alquran, karena yang mereka cari adalah maksud dan tujuan dari makna-makna literal itu ayat-ayat tersebut.

Ketiga, berbeda dengan tafsir klasik yang menggunakan praktek penafsir yang linieratomistik seperti diurai di atas, tafsir kontemporer memiliki paradigma yang bernuansa hermeneutik. Menurut, Roger Trigg hermeneutika merupakan suatu model penafsiran terhadap teks tradisional (klasik), dimana suatu permaslahan harus selalu diarahkan agar teks selalu dapat dipahami dalam pada konteks kekinian yang situasinnya berbeda. ${ }^{29}$ Nuansa hermeneutika yang menonjol pada tafsir kontemporer, membuat mereka selalu curiga pada adanya kepentingan ideologis yang ada di balik teks tersebut. ${ }^{30}$ Poin ini yang membuat tafsir kontemporer selamat dari sektarianisme,seperti yang pernah dialami oleh mayoritas tafsir klasik.

Keempat, paradigma tafsir yang terahir ini adalah konsekwensi logis dari tiga paradigma di atas, karena tafsir kontemporer itu didasarkan pada semangat membuktikan Alquran sebagai hidayah, rahmat untuk semua penghuni alam, menggunakan hermeuneutika, sehingga terbebas dari pandangan sektaria- nisme, maka paradigma tafsir kontemporer itu kritis dan ilmiah.

Menurut Mustaqim, keilmiahan bisa dilihat dari produk tafsir kontemporer yang dapat diuji kebenarannya berdasarkan konsistensi metodologi yang dipakai dan siap menerima kritik dari komunitas akademik. Selain itu, tafsir kontemporer disebut kritis karena umumnya mufasir kontemporer tidak terjebak pada fanatisme mazhab, mereka justru kritis terhadap beberapa pandanganklasik atau kontemporer yang dianggaptidak kompatibel dengan konteks kekiniaan. ${ }^{31}$

Istilah pendekatan dalam kajian metodologi tafsir masih sering diperdebatkan. Mungkin karena kajian tentang metodologi tafsir masih terbilang baru jika dibandingkan dengan tafsir dalam arti produk tafsir. Istilah pendekatan biasa di sebut dengan ittijah al-tafsir atau lebih populer dengan istilah corak tafsir.

Ada beberapa istilah bahasa Arab yang sering diartikan dengan corak, yaitu: ittijäh, naz'ah, al-lawn, al-tayyār atau al-rawāfid. Dari sekian kata tersebut, yang mendekati makna sesungguhnya adalah kata ittijah

Sebagian tokoh ada yang membedakan antara sumber dan corak penafsiran dan ada pula yang tidak membedakannya. Tokoh yang membedakan antara sumber dan corak penafsiran antara lain: 'Abd al-Majīd 'Abd alSalām al-Muhtasib, 'Iffat al-Syarqāwì, dan Labīb Sa'id. Sedangkan tokoh-tokoh selain mereka tidak membedakan antara corak dan sumber penafsiran.

Berdasarkan teori yang ada, maka corak tafsir adalah kecenderungan yang dimiliki oleh masing-masing penafsir, yang kemudian menjadi pandangan atau trade mark mereka dalam tafsirnya sekaligus warna pemikiran mereka terhadap ayat-ayat Alquran. Oleh sebab itu, keberadaan corak tafsir tidak bisa ditentukan keberadaannya hanya untuk tafsir yang menggunakan metode tertentu saja.

\footnotetext{
${ }^{29}$ Komaruddin Hidayat, Memahami Bahasa Agama (Jakarta: Paramadina, 1996), 62.

${ }^{30}$ Ibid.
} 
Dari berbagai teori tentang ittijāh tafsir (corak tafsir) yang diajukan para pakar 32itu, pada dasarnya dapat dikelompokkan kepada dua alasan, yaitu:

a. Corak tafsir muncul disebabkan latar belakang penafsir ketika menafsirkan Alquran. Hal ini sesuai dengan kaidah dalam ilmu tafsir (التفسير متأثر بثقافة المفسر).

b. Corak tafsir muncul didasarkan kepada tujuan yang telah ditetapkan terlebih dahulu oleh penafsir pada saat akan menafsirkan Alquran ( الهدف الذي يتجه اليه (المفسر).

Menurut hemat penulis, dua alasan di atas,mengarah pada kesimpulan bahwa corak tafsir itu sama dengan pendekatan tafsir. Oleh karena itu, pada saat akan membuat penilaian tentang pendekatan suatu tafsir harus telebih dahulu diketahui apakah berdasarkan kepada latar belakang penafsir atau tujuan yang telah ditetapkan terlebih dahulu oleh penafsir. Jika hal ini tidak dilakukan, yang terjadi adalah ketidak tepatan dalam penilaian. Boleh jadi seorang penafsir yang berlatar belakang bahasa pada saat menafsirkan mempunyai tujuan menjelaskan aspek sosial, maka coraknya tidak bisa disebut sebagai tafsir yang bercorak bahasa melainkan tafsir ijtimāî́, seperti Tafsir al-Marāgí.

Sesuai dengan tantangan dan prinsip tafsir kontemporer, ditambah dengan beberapa alasan akan keniscayaan pergesaran epistemologi

\footnotetext{
${ }^{32}$ Tokoh-tokoh yang mengemukakan macammacam corak tafsir antara lain: Muhammad Husayn al-Dzahabî, Ahmad al-Syarâbâshî, 'Abd al-Majîd 'Abd al-Salâm al-Muhtasib, al-Sayid Ahmad Khalîl, Fahd Sulaimân al-Rûmî, 'Iffat alSyarqâwî, 'Abd al-Hayy al-Farmâwî, Labîb Sa'îd, Mushthafâ al-Shâwî al-Juwainî, Muhammad 'Abd al-'Adhîm al-Zarqânî, Bakri Syaikh Amîn, 'Alî Hasan al-'Arîdl.

Ibrahîm Syarîf memberikan definisi corak atau ittijah al-tafsîr sebagai berikut:

الإتجاهالتفسيريدلاساساعلنميمو عةمنالمبادنالتبيربطهاطار نظربوتهدف إلنغايةبعينها

Definisi tersebut memiliki kesamaan dengan apa yang dikemukakan oleh Fahd al-Rûmî, yaitu:

الإتجاههو الهدفالذييتجهالِيهالمفسرو نفتفاسير همويجعلونهنصبأعينهمو

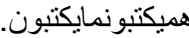

tafsir tiap kurun yang telah dipaparkan di awal. Maka, tafsir abad ini memiliki ragam pendekatan yang berbeda dengan abad sebelumnya.

Menurut analisa penulis beberapa pendekatan tafsir kontemporer yang ada sebagai berikut; pertama pendekatan ilmiah. Tafsir dengan pendekatan ilmiah mengharuskan penafsir dalam memahami ayat-ayat Alquran cenderung menyelaraskan antara teori ilmiah atau aspek metafisika alam dengan ayat Alquran. Alquran yang bersifat universal telah memberikan gambaran seluas-luasnya tentang fenomena alam semesta, yang ternyata setelah dicocokkan sangat berkesesuaian dengan teori ilmu pengetahuan yang dimiliki manusia pada masa ini.

Kedua Pendekatan semantik. Sebagai kalam Allah, Alquran bersifat transenden dan transhistoris. Namun karena disampaikan dalam bahasa manusia, maka Alquran juga imanen dan historis. Susunan teks Alquran yang dipercaya sesuai dengan susunan di lawh al-mahfü berbeda dengan urutan diturunkannya. Jumlah kata-kata Alquran adalah terbatas, sedang ruang-waktu pemberlakuannya hampir tak terbatas. Fakta-fakta ini tampaknya dapat menjadi alasan yang cukup untuk mengatakan bahwa kompleksitas makna Alquran itu demikian tinggi, apalagi jika hendak difahami pada masa yang sangat jauh dengan masa penurunannya, seperti sekarang ini.

Untuk menangkap pesan dan informasi Alquran secara mendalam dan komprehensif, seiring perkembangan ilmu, teknologi, dan peradaban manusia, diperlukan kajian metodologi yang semakin canggih. Salah satu pendekatan kajian Alquran yang tampaknya berhasil mengungkapkan gagasan Alquran secara mendalam dan komprehensif, mengenai pandangan dunia dan konsep-konsep etikareligus Alquran, adalah pendekatan semantik, seperti yang dilakukan Toshihiko Izutsu. ${ }^{33}$

\footnotetext{
${ }^{33}$ Reputasi Izutsu terutama dalam studi Islam dapat dilihat dari satu seminar internasional khusus tentang karya-karyanya di Universitas Islam Internasional di Malaysia pada 4-6 Agustus 2008, dan menghasilkan
} 
Pendekatan ini mengharuskan penggunanya menguasai bahasa Arab dengan baik hingga sya'ir-sya'ir jāhilī.

Ketiga pendekatan hermeneutika, Pendekatan hermeneutika telah mengilhami para sarjana muslim kontemporer untuk membuka wacana baru, seperti Arkoun, Hasan Hanafi, Farid Esack dan Nasr Hamid Abu Zaid, dalam melakukan interpretasi. ${ }^{34}$

Konsekuensi dari model hermeneutika, dalam menafsirkan Alquran tidak hanya mengandalkan perangkat keilmuan seperti yang digunakan para penafsir dulu, seperti ilmu naḥwu sharaf, ushūl fiqh danbalāghah, tetapi diperlukan ilmu-ilmu lain seperti teori sosiologi, antropologi, filsafat ilmu, sejarah, gender dan sebagainya. Metode hermeneutika yang dikembangkan oleh para penafsir kontemporer itu pun sangat beragam. Keberagaman ini muncul bukan hanya karena semakin terbukanya umat Islam terhadap gagasan-gagasan yang berasal dari luar, seperti isu tentang HAM, gender, demokrasi, civil society, pluralisme dan sebagainya, namun juga karena adanya dinamika dan kesadaran pada mereka akan kekurangan-kekurangan metode dan pendekatan yang ada selama ini.

Dengan kentalnya nuansa hermeneutik, maka peran teks, pengarang dan pembaca

tulisan Consciousness and Reality: Studies in Memory of Toshihiko Izutsu, ed. by Sayyid Jalāl al-Dīn Āshtiyānī, et al. (Leiden: Brill, 2000). ${ }^{33}$ Ia sempat di review oleh W. Montgomery Watt sebagai the first Japanese to write on Islam in a European language, (dalam "Reviews," Journal of Semitic Studies, vol. 12, no. 1 (1967), p. 156; Harry B. Partin, "Semantics of the Qurıān: A Consideration of Izutsu's Studies," History of Religions 9, no. 4 (1970).

${ }^{34}$ Sebagaimana dinyatakan Roger Trigg bahwa paradigma hermeneutik adalah:

"The paradigm for hermeneutics is interpretation of the traditional text, where the problem must always be how we can come to understand in our own context something which was written in radically different situation" Terjemahan bebasnya, bahwa paradigma hermeneutik adalah suatu penafsiran terhadap teks tradisional (klasik), di mana suatu permasalahan harus selalu diarahkan bagaimana supaya teks tersebut selalu dapat kita pahami dalam konteks kekinian yang situasinya sangat berbeda.Komaruddin Hidayat, Memahami Bahasa Agama, 161. menjadi berimbang, sehingga kesewenangwenangan dan pemaksaan penafsiran relatif dapat dihindari. Dengan demikian, meminjam istilah Khalid Aboul Fadl, otoritarianisme penafsiran dapat dieliminasi dan produkproduk tafsir menjadi lebih otoritatif, tidak otoriter dan despotic. ${ }^{35}$

Setiap penafsir pasti sudah memiliki prejudice sebelum berhadapan dengan teks. Jadi, sebuah penafsiran pasti melibatkan subjektivitas penafsir. Penafsiran atas kitab suci tidak hanya bersifat reproduktif, tapi juga produktif. Dalam konteks ini Hans-Georg Gadamer mengatakan, "That is why understanding is not merely a reproductive, but always a productive attitude as well." 36 Kita tidak mungkin membaca teks tanpa prasangka (prejudice, Vorurteil) dan kita tidak mungkin memahami teks kalau tidak menambah makna terhadap makna yang sudah ada. Namun demikian, sebenarnya Gadamer tidak berhenti di situ, karena dengan mengikuti 'lingkaran hermeneutic', ia menganggap bahwa bisa terjadi penggabungan kedua cakiawala (fusion of the two horizons). Yang dimaksud penggabungan dua cakrawala adalah bahwa kita tidak berarti selalu akan menghasilkan sebuah campuran yang seimbang di antara masa lalu (kuno) dan cakrawala masa kini (modern). Juga tidak berarti bahwa cakrawala masa kini akan mendominasi cakrawala masa lalu. Sebaliknya makna asli itu dapat diperoleh dari penggabungan kedua cakrawala. Artinya, kita perlu memeriksa makna teks bagi orang di masa lalu (what it means) dengan jalan exegese, sesudah itu kita baru mencari makna teks bagi masa kini (what its means) melalui hermeneutika. ${ }^{37}$ Dengan begitu, maka teks itu menjadi "hidup" dan kaya akan makna. Teks itu akan menjadi dinamis pemaknaannya dan

\footnotetext{
${ }^{35}$ Khaled Abou ElFadl, Atas Nama Tuhan: Sari Fikih Otoriter Ke Fikih Otoritatif (Jakarta: Serambi Ilmu Semesta, 2004).

${ }^{36}$ Hans-Georg Gadamer, Truth and Method (New York: The Seabury Press, 1975), 264.

${ }^{37}$ Pdt. E. Gerrit Singgih, Mengantisipasi Masa Depan; Berteologi Dalam Konteks Di Awal Melenium III (Jakarta: PT BPK Gunung Mulia, 2005), 3637 dan 4042.
} 
selalu kontekstual, setring dengan akselerasi perkembangan budaya dan peradaban manusia. $^{38}$

Oleh sebab itu, wajar jika teks yang tunggal, lalu dibaca oleh banyak pembaca (readers), menghasilnya banyak wajah penafsiran. Menarik untuk dikutip dalam hal ini adalah pendapat Amina Wadud yang mengatakan: "Although each reading is unique, the understanding of various readers of singel text will converge on many points." 39 Menurutnya, karena selama ini tidak ada metode tafsir yang benar-benar objektif. Masing-masing interpretasi cenderung mencerminkan pilihan-pilihan yang subjektif. ${ }^{40}$

Lalu bagaimana agar sebuah penafsiran itu relatif lebih objektif. Menurut Amina Wadud, untuk memperoleh penafsiran yang relatif objektif, seorang penafsir harus kembali pada prinsip-prinsip dasar dalam Alquran sebagai ketangka paradigmanya dan seorang penafsir perlu memahami Weltanchauung atau world view. ${ }^{41}$ Gagasan tentang perlunya memahami Weltanschauung sebenarnya merupakan ide dari Fazlur Rahman. Gagasan ini dirumuskan dengan menggunakan prosedur sintesis antara sistem etika dan teologi. ${ }^{42}$

Keempat, Pendekatan ilmu-ilmu sosial, pendekatan ini sebenar tidak terlalu baru, pendekatan ini sudah dikenal di awal abad moderen yang lalu. Persentuhan dengan peradaban barat disebut-sebut sebagai stimulus lahirnya pendekatan ini dalam dunia Islam. Kemampuan para penafsir kontemporer dalam memahami ilmu-ilmu sosial, dijadikan modal untuk memahami gejala-gejala keagamaan yang sejauh ini hanya didasarkan pada ilmu-ilmu agama. Mereka tampaknya sangat menyadari bahwa ilmu sosial yang berasal dari Barat itu sangat penting untuk memahami

\footnotetext{
${ }^{38}$ Hassan Hanafi, Al-Yamin Wa Al-Yasar Fi Al-Fikr Al-Dini (Mesir: Madbuli, 1989), 77.

${ }^{39}$ Amina Wadud, "Qur'an and Woman" dalam Charles Kurzman, Liberal Islam, 127.

${ }^{40}$ Ibid., 128.

${ }^{41}$ Amina Wadud Muhsin, Qur'an and Woman (Kuala Lumpur: Fajar Bakti Sdn bhd, 1994), 5.

${ }^{42}$ Fazlur Rahman, Major Themes of The Qur'an (Chicago: Bibliotecha Islamica, 1980), xi.
}

(mengkritik) gejala (agama) yang ada dalam dunia Islam selama ini. Riffat Hassan misalnya, dengan terang-terangan mengakui perlunya mengembangkan apa yang oleh Barat disebut dengan "teologi feminis" untuk membebaskan umat Islam dari struktur yang tidak adil dan tidak memungkinkan terjadinya hubungan yang hidup antara laki-laki dan perempuan. ${ }^{43}$

Sebenarnya, pendekatan ilmu sosial ini sudah dimulai sejak abad moderen. Pendekatan ini dikenal dengan al-tafsir al-ijtimā'î. Tafsir ini masih diminati pada abad kontemporer hanya ada sedikit perubahan pada asumsi dan prinsip yang digunakan. Misalnya pendekatan ini di abad kontemporer kerapkali dikolabarasi dengan pendekatan lain sehingga menghasilkan tafsir Alquran yang berbeda meskipun pada kasus dan ayat yang sama.

Kelima, pendekatan yang bersifat mengarah pada pembebasan, untuk contoh penulis memilih pendekatan feminisme atau gender. Gender sebagai gejala sosial,dapat diartikan sebagai pembagian peran manusia berdasarkan jenis kelamin. Tujuan perjuangan feminisme pada umumnya mencapai kesetaraan, harkat dan kebebasan perempuan dalam memilih untuk mengelola kehidupan tubuhnya, baik diluar maupun di dalam rumah tangga. Namun sebagaimana yang dikatakan NighatSaid Khan dan Kamla Bashin ${ }^{44}$ dua feminis asal India, feminis tidak hanya bertujuan memperjuangkan persamaan laki-laki dan perempuan, melainkan juga membangun tatanan masyarakat yang adil dan baik bagi perempuan maupun laki-laki, bebas dari pengisapan dan pengkotakan berdasarkan kelas, kasta, dan prasangka jenis kelamin. Persoalan mendasar dalam membahas isu-isu gerakan feminisme adalah tentang posisi perempuan dalam tafsir Alquran adalah masih adanya kesenjangan anatara tataran ideal-normatif yang dijarakan Alquran dengan tataran tafsir yang historis-empiris.

\footnotetext{
${ }^{43}$ Riffat Hassan, Setara di Hadapan Allah, 40.

${ }^{44}$ Kamla Bashin dan Nighat Said Khan, Persoalan Pokok Mengenai Feminisme Dan Relevansinya (Jakarta: Gramedia Pustaka Utama dan Kaylamitra, 1995), 56.
} 
Jika dalam tataran normatif-idealis, kaum perempuan dipandang setara dengan laki-laki, namun pada tataran historis-empiris posisi perempuan relatif belum setara dengan lakilaki, peranan perempuan terasa masih terpinggirkan. Ini berarti masih ada kesenjangan antara yang semestinya (normative) dengan yang senyata.

Bagi pengkaji masalah perempuan, agama merupakan salah satu obyek kajian yang sangat menarik. Hal ini karena agama, yang merupakan way of life sebagian besar umat manusia, mengandung ajaran-ajaran yang berkaitan dengan hal tersebut di dalam kitabkitab sucinya. Selama ini penafsiran para elit agama atas teks-teks keagamaan dalam kaitannya dengan masalah perempuan cenderung 'menomorduakan' pihak perempuan, dan di banyak tempat teks-teks keagamaan itu sendiri secara harfiah memang menempatkan laki-laki di atas perempuan.

Pendekatan ini sangat berkonsentrasi pada pencaraian sebab lahirnya kesenjangan diatas yang umumnya merajalela di tafsir klasik. Dengan pendekatan feminis, para mufasir kontemporer mengajukan paradigma dan asumsi baru tentang pembacaan ulang pada Alquran berdasarkan pada semangat dan tujuan di atas.

Keenam, pendekatan pluralisme agama, Budhi Munawar Rahman menyimpulkan bahawa filsafat atau teologi pluralisme dan dialog antar umat beragama mensyaratkan dialog antar umat beragama sebagai elemen penting dalam berinteraksi dengan agamaagama lain. Dialog ini bukan bertujuan menciptakan satu agama tunggaldan final, melainkan memperkaya dan merayakan keberagaman yang semakin berkembang dan berarti dalam agama-agama. Dialog korelasional ini harus disertai dengan tanggungjawab global, oleh karena itu pendekatannya bukan eklesiosentris, kristosentris atau teosentris melainkan soterosentris (berpusat pada keselamatan) yang didasarkan pada dasar yang sama, yaitu tanggung jawab global terhadap kesejahteraan manusia dan lingkungan. ${ }^{45}$

Dasar dialog antara agama bagi pluralisme dan dialog antaragama adalah soal penderitaan manusia dan kerusakan ekologi, atau dengan kata lain kesejahteraan manusia dan lingkungannya. Dengan pendekatan ini, beberapa ayat Alquran yang biasa ditafsirkan membedakan atau mengaggap eksklusif ajaran agama Islam dan menyalahkan agama selain Islam, ditafsirkan ulang dengan asumsi dan paradigma di atas. Sehingga tercapai tujuan hidup penuh damai dan tidak adalagi kekerasaan atas nama agama.

\section{Standar Validitas Tafsir Kontemporer}

Menurut Thomas Kuhn, sebagaimana dikutip oleh Ian Barbour, teori dalam sains bergantung pada paradigmanya. ${ }^{46}$ Oleh karena itu sebuah paradigma dalam setiap disiplin ilmu menempati poisisi penting. karena meniscayakan adanya asumsi metodologis. Asumsi inilah yang akan dipergunakan dalam menganalisa, ia berupa totalitas premis-presmis dan metodologis yang menentukan suatu studi ilmiah, serta dasar untuk menyeleksi problem dan pola untuk memecahkan problem-problem riset. Selain itu, paradigma juga bisa dimaknai sebagai seperangkat pra-anggapan konseptual, metafisik, dan metodologis dalam tradisi kerja ilmiah. ${ }^{47}$

\footnotetext{
45 Dalam kata pengantar buku Gerardette Philips, Melampaui Pluralisme (Malang: Madani, 2016)xxi.

${ }^{46}$ Istilah paradigma (Inggris: paradigm) sebenamya berasal dari bahasa Yunani,yaitu paradeigma, dari kata para (di samping, di sebelah) dan dekynai (model, contoh). Paradigma dapatdiartikan sebagai cara memandang sesuatu, totalitaspremis-presmis dan metodologis yang menentukan suatu studi ilmiah, serta dasar untuk menyeleksi problem dan pola untuk memecahkan problem-problem riset. Selain itu, paradigma juga bisa dimaknai sebagai seperangkat pra anggapan konseptual, metafisik, dan metodologis dalam tradisi kerja ilmiah. Lihat Lorens Bagus, Kamus Filsafat, (Jakarta: PT Gramedia Utama, 1996), hlm. 779. Bandingkan dengan Ian Barbour, Juru Bicara Tuhan; Antara Sains dan Agama, (Bandung: Mizan, 2003), hlm. 81.

${ }^{47}$ Lihat Lorens Bagus, Kamus Filsafat, (Jakarta: PT Gramedia Utama, 1996), hlm. 779. Bandingkan dengan Ian Barbour, Juru Bicara Tuhan; Antara Sains dan Agama, (Bandung: Mizan, 2003), hlm. 81.
} 
Paradigma sebagai pandangan ontologis seorang penafsir dalam melihat subject matter yang hendak dikaji. Sebuah paradigma dalam setiap disiplin ilmu, pasti memiliki asumsi, metode dan pendekatan tertentu, yang berbeda dari paradigma yang lain. Asumsi-asumsi ini akan dipergunakan dalam analisisnya.

Jika tafsir Alquran di era kontemporer memiliki asumsi paradigma yang berbeda dengan tafsir di zaman klasik. Maka tafsir Alquran di era kontemporer juga memiliki parameter kebenaran tafsir yang berbeda dengan parameter kebenaran tafsir Alquran di era kontemporer. Ini adalah keniscayaan karena menentukan ukuran kebenaran objek harus sama dengan pandangan subjek terhadap objek.

Para mufasir klasik pada umumnya memandang tafsir dengan paradigma teknis, bahwa tafsir merupakan ilmu yang mengkaji tentang teknis dan cara mengucapkan lafallafal Alquran, apa yang ditunjukan oleh lafallafal itu, hukum-hukum lafal tersebut, baik ketika berdiri sendiri atau ketika ada dalam rangkaian kalimat, termasuk pula mengkaji tentang makna-makna yang terkandung di dalamnya, dan hal-hal lain yang mendukung kesempurnaan penafsiran, seperti ilmu nasikhmansukh, sababal-Nuzul dll ${ }^{48}$. Maka Berbeda dengan mufasir di abad kontemporer yang menggunakan paradigma fungsional, maka hakikat tafsir adalah ilmu yang digunakan untuk memahami kitab Allah (Alquran) yang diturunkan kepada Nabi Muhammad, menjelaskan makna-maknanya dan menggali hukum-hukum serta hikmah-hikmah yang ada didalamnya, sehingga Alquran itu dapat benarbenar berfungsi sebagai petunjuk bagi manusia. Dimana ilmu bahasa sebagai dasar pijakannya $^{49}$

Meskipun demikian, sebenarnya antara mufasir klasik dan mufasir kontemporer memiliki pandangan yang sama tentang objek material tafsir yakni Alquran, sedang objek

48 Hakika tafsir sperti itu dikemukan oleh Abu Hayyan al- Andalusi

${ }^{49}$ Hal ini dapat dilihat pada definisi tafsir dari alZarkasyi dan al-Suyuthi. formal tafsir itu adalah problem pemberian makna dan memproduksi makna untuk mengungkap maksud firman Allah.

Berdasarkan pada pandangan ontologis pada Alquran seperti di atas, maka para penafsir kontemporer memiliki asumsi bahwa 1) Alquran sebagai kitab petunjuk maka ia harus menjadi rahmat bagi seluruh alam, 2) tafsir Alquran adalah sesuatu yang berbeda dengan Alquran, maka tafsir itu bersifat relatif dan tentatif, 3) menafsirkan Alquran sebagai upaya memahami maksud Allah, meniscayakan penggunaan kerangka kerja hermeneutika 4) tafsir Alquran tidak boleh memihak pada kepentingan mazhab tertentu. Artinya tafsir harus terbuka, kritis dan ilmiah.

Berdasarkan pada asumsi tersebut, kemudian para mufasir kontemporer memiliki paradigma bahwa 1) tafsir itu harus bersifat kontekstual dengan mengacu pada prinsip keuniversalan Alquran yakni ; al-Huriyyah, al-Adalah, al-musawah, al-Insaniyah, 2) tafsir harus mengacu pada spirit Alquran 3) tafsir Alquran harus bersifat terbuka untuk dikritisi agar tidak jadi teks suci, 4) menafsir Alquran berarti menggunakan pendekatan historis, sosiologis, hermeneutis dan lain-lain.

Menentukan parameter kebenaran pada tafsir sebagai produk pemikiran manusia memang bukan hal yang mudah, namun berdasarkan pada beberapa pendapat di atas yang menjelaskan bahwa asumsi paradigmatis dapat berfungsi sebagai pola dalam menagalisa dan memecahkan problem riset, maka kiranya dapat diketahui bahwa perbedaan asumsi dan paradigma akan melahirkan pola dan standar kebenaran yang berbeda.

Mufasir klasik sebagai subjek yang sudah memandang objek (tafsir) sebagai sesuatu yang lebih teknis akan memiliki parameter kebenaran tafsir pada hal- hal yang teknis juga. Yakni: 1) sebuah tafsir dianggap benar jika merujuk pada sebuah riwayat yang matan atau sanad shahih, 2) benar tidaknya tafsir ditentukan dengan sesuai atau tidaknya hasil penafsiran dengan kaidah - kaidah kebahasaan dan riwayat hadits yang shahih. 3) tujuan menafsirnya untuk kepentingan kelompok, 
mendukung kekuasaan, mazhab, atau ilmu yang ditekuni oleh mufasir. ${ }^{50}$

Sedangkan mufasir kontemporer yang memandang objek (tafsir) dengan paradigma fungsional, maka bagi mereka tafsir bukan sekedar persoalan cara pengucapan lafal, hukum lafal, makna lafal, dan kandungan lafal saja. Bagi mereka tafsir ilmu untuk mengetahui maksud Allah, menjelaskan makna kata, menggali hukum dan hikmahnya, dan yang terpenting tafsir harus berfungsi sebagai alat yang menunujakan fungsi Alquran sebagai petunjuk bagi manusia dengan ilmu bahasa sebagai dasar pijakannya. Selain itu, asumsi paradigmatis mufasir kontemporer juga memberikan andil besar dalam menentukan parameter kebenaran tafsir di abad kontemporer ini. 1) tasir itu harus bersifat solutif dan responsif pada persoalan dan kepentingan transformasi umat, 2) harus mengacu pada spirit Alquran dan prinsip nilai universal dalam Alquran 3) tafsir sebagai sebuah pemikiran manusia yang tentatif dan relatif maka harus ada kesesuaian antara tafsir dengan fakta empiris. 4) tafsir sebagai sebuah produk ilmiah maka harus ada kesesuaian antara hasil tafsir dengan proposisi - proposisi yang dibangun sebelumnya.

\section{SIMPULAN}

Asumsi dasar Tafsir kontemporer dibangun berdasarkan beberapa asumsi, yakni pertama Alquran itu kitab hidayah yang rahmatan lil àlamin, kedua, tafsir Alquran itu sesuatu yang berbeda dengan Alquran itu sendiri aka ia bersifat relatif dan tentatif ketiga, menafsir sebagai upaya memahami maksud Allah yang turun ratusan tahun lalu meniscayakan penggunaan hermenutika dalam menangkap pesan idealnya. Keempat tafsir itu harus terbuka kritis dan ilmiah. Diatas asumsi itu dibangun paradigma tafsir kontemporer yang 1). Tafsir harus kontekstual dan mengacu pada prinsip nilai universal. 2)tafsir harus mengacu pada spirit Alquran. 3) tafsir Alquran harus terbuka untuk dikritisi, 4)tafsir harus mengggunakan

\footnotetext{
${ }^{50}$ Mustaqim, Epistemologi Tafsir Kontemporer, 51.
}

pendekatan sosiologis, historis dan hermeneutis. Metode tafsir kontemporer umumnya tematik dan bersumber pada tafsir bi al-Ra'yi (tafsir rasional).

\section{DAFTAR PUSTAKA}

A.W. Munawir. Kamus Al-Munawir ArabIndonesia Lengkap. Surabaya: Pustaka Progresip, 1997.

Abdul Hamid Al-Bilali. Al-Mukhtashar AlMashun Min Kitab Al-Tafsir Wa AlMufashirun. Kuwait: Dar al-Dakwah, 1405. Abdullahi Ahmad An-Naim. Dekonstruksi Syari'ah. Yogyakarta: LKiS, 1994.

Ahmad Syirbasi. Studi Tentang Sejarah Perkembangan Tafsir Al-Qur'anul Karim. Jakarta: Kalam Mulia, 1999.

Ahmad Syukri. Metodologi Tafsir Al-Qur`an Kontemporer Dalam Pandangan Fazlur Rahman. Jambi: Sulton Thaha Press, 2007.

Anonim. Oxford Learner's Pocket Dictionary, New Edition. Oxford: Oxford University Press, 2006.

Anwar, Rosihon. Samudra Al-Qur'an. Bandung: Pustaka Setia, 2001.

ElFadl, Khaled Abou. Atas Nama Tuhan: Sari Fikih Otoriter Ke Fikih Otoritatif. Jakarta: Serambi Ilmu Semesta, 2004.

Gerardette Philips. Melampaui Pluralisme. Malang: Madani, 2016.

Hanafi, Hassan. Al-Yamin Wa Al-Yasar Fi AlFikr Al-Dini. Mesir: Madbuli, 1989.

Hans-Georg Gadamer. Truth and Method. New York: The Seabury Press, 1975.

Harb, Ali. Naqd Al-Nash. Beirut: al-Markaz al-Tsaqafi, 1995.

Harry B. Partin. "Semantics of the Qurān: A Consideration of Izutsu's Studies." History of Religions 9, no. 4 (1970).

Kamla Bashin dan Nighat Said Khan. Persoalan Pokok Mengenai Feminisme Dan Relevansinya. Jakarta: Gramedia Pustaka Utama dan Kaylamitra, 1995.

Komaruddin Hidayat. Memahami Bahasa Agama. Jakarta: Paramadina, 1996.

Kuntowijoyo. Islam Sebagai Ilmu. Yogyakarta: Tiara Wacana, 2006.

M. Quraisy Shihab. Membumikan Al-Qur'an. Bandung: Mizan, 1998. 
Muhsin, Amina Wadud. Qur'an and Woman. Kuala Lumpur: Fajar Bakti Sdn bhd, 1994.

Mustaqim, Abdul. Epistemologi Tafsir Kontemporer. Yogyakarta: LKiS, 2012.

Nurcholish Setiawan. "Al-Qur'an Dalam Kesejarahan Klasik \& Kontemporer." Jurnal Study Al-Qur'an, 2006.

Pdt. E. Gerrit Singgih. Mengantisipasi Masa Depan; Berteologi Dalam Konteks Di Awal Melenium III. Jakarta: PT BPK Gunung Mulia, 2005.

Pusat Bahasa Departemen Pendidikan Nasional. Kamus Besar Bahasa Indonesia. Jakarta: Gramedia, 2003.

Qaththan, Manna' Khalil. Studi Ilmu-Ilmu AlQur'an. Jakarta Timur: Pustaka al-Kautsar, 2008.

Rahman, Fazlur. Major Themes of The Qur'an. Chicago: Bibliotecha Islamica,
1980.

Sadily, John M. Echols dan Hasan. Kamus Inggris-Indonesia. Jakarta: Gramedia, 2003.

Suyuthi, Al-Hafizh al-Imam Jalaluddin. AlItqan. Kairo: Dar At-Turath, n.d.

Thanthawi, Muhammad Sayyid. Mabahits Fi "Ulum Al-Qur"an. Kairo: Azhar Press, 2003.

Tibi, Bassam. "Moralitas Internasional Sebagai Suatu Landasan Lintas Budaya." In Agama Dan Dialog Antar Peradaban. Jakarta: Yayasan Wakaf Paramadina, 1996. Yusuf, Yunan. "Karakteristik Tafsir AlQur'an Di Indonesia Abad Ke-20.” Jurnal Ulumul Qur'an 4 (1992). 